Satya Widya : Jurnal Studi Agama Vol. 3 No. 22020

$P-I S S N$ : 2623-0534

E-ISSN : 2655-1454

Website Jurnal : https://ejournal.iahntp.ac.id/index.php/satya-widya/index

DOI: https://doi.org/10.33363/swjsa.v3i2.592

\title{
AMALAN SAMPAINGAT LOCAL GENIUS HINDU KAHARINGAN
}

\author{
Komang Suarta \\ Institut Agama Hindu Negeri Tampung Penyang Palangka Raya \\ adhisakti.siwa@gmail.com
}

\begin{abstract}
Riwayat Jurnal
Artikel diterima: 30 Nopember 2020

Artikel direvisi: 29 Desember 2020

Artikel disetujui: 29 Desember 2020
\end{abstract}

Kata Kunci:

Amalan Sampaingat

Local Genius

Hindu Kaharingan

Keyword:

Amalan Sampaingat

Local Genius

Hindu Kaharingan

\begin{abstract}
Abstrak
Aspek muatan lokal dan berwawaskan potensi keunggulan Hindu etnis Dayak Kalimantan Tengah, maka akan kita jumpai kearifal lokal seperti "hidup menyatu dengan alam". Kearifan lokal sangat diperlukan untuk menyiapkan sebuah generasi yang tidak hanya bisa menjadi penonton dalam sejarah peradaban, akan tetapi bisa menjadi pelaku sejarah dari peradaban itu sendiri. Amalan Sampaingat merupakan sebuah warisan dari leluhur Dayak Kalimantan Tengah yang merupakan sebuah metode untuk menciptakan kecerdasan pada orang yang mengamalkannya. Amalan ini terdiri atas dua cara, yakni melalui menginang dan dengan cara permandian (keramas).

Abstract

In terms of local content and taking into account the potential superiority of the Dayak Hindu people of Central Kalimantan, we will encounter local wisdom such as "living one with nature". Local wisdom is indispensable to prepare a generation that can not only be spectators in the history of civilization, but can become actors in the history of civilization itself. The Sampa Remember practice is a legacy from the Dayak ancestors of Central Kalimantan which is a method for creating intelligence in those who practice it. This practice consists of two ways, namely through chewing and by bathing (shampooing).
\end{abstract}

Satya Widya : Jurnal Studi Agama Vol. 3 No. 22020

DOI: https://doi.org/10.33363/swjsa.v3i2.592 


\section{Amalan Sampaingat Local Genius Hindu Kaharingan}

Komang Suarta

\section{Pendahuluan}

Dari waktu ke waktu, manusia menunjukan eksistensinya sebagai salah satu mahluk yang memiliki kecerdasan dalam berinteraksi dengan alam semesta. Berbagai mahluk hidup di dunia ini masing-masing memiliki kemampuan daya ingat tentang pengalaman yang diperolehnya dalam menjalani kehidupan ini. Berbagai burung terbang jauh dari sarangnya atau tepatnya beristirahat ketika malam, namun mereka tetap kembali menjelang malam mereka tetap kembali ke sarang atau tempatnya masing masing. Demikian pula dengan berbagai binatang yang memiliki kebiasaan serupa. Hal ini menunjukan bahwa mereka juga memiliki daya ingat sebagaimana yang dimiiki oleh manusia.

Sangat menarik jika menyelami kehidupan manusia, karena manusia tidak hanya melakukan aktivitas mengingat yang sifatnya terbatas yang dilakukan oleh mahluk lain. Jika mahluk lain kesehariannya dilakukan hanya mengingat kebiasaan-kebiasaan sederhana, lebih dari itu manusia melakukan suatu hal yang sifatnya lebih kompleks. Berbagai rupa yang mendeskripsikan bentuk ditangkap melalui mata sebagai indra penglihat. Bermacam-macam gelombang suara suara ditangkap melalui telinga sebagai indra pendengaran. Beraneka macam rasa yang dikecap oleh lidah sebagai indra pengecap. Hidung juga tidak kalah dengan yang lainnya, ia juga menjalankan fungsinya untuk memberika informasi variasi bebauan yang tercium olehnya. Demikian pula halnya dengan Kulit yang menjadi indra peraba, ia memberikan berbagai informasi terhadap benda-benda yang disentuh. Aktivitas yang dilakukan manusia lebih kompleks dari aktivitas mahluk lainnya. Segala bentuk aktivitas tersebut terekam oleh pikiran manusia melalui perantara paca indranya, namun tidak semua dari hal itu bisa diingat olehnya, tergantung bagaimana masingmasing dari manusia tersebut dalam memahami pikiran dan objek yang mempengaruhinya melalui panca indranya tersebut. Inilah yang membuat manusia memiliki kecerdasan berbeda-beda antara yang satu dengan yang lainnya.

Setiap orang menginginkan untuk memiliki tingkat kecerdasan yang tinggi, namun tidak semua dari mereka mau mengupayakan untuk mencapainya. Dari berbagai belahan dunia, manusia memiliki caranya masing-masing agar mempunyai kecerdasan. Pola hidup untuk mengelola pikiran memang menjadi hal yang semestinya mendapat perhatian untuk memperoleh kecerdasan tersebut. Apalagi yang membuat manusia dikatakan memiliki kelebihan dari mahluk lain adalah karena memiliki alat yang disebut Pikiran. Manusia dikatakan adalah mahluk yang utama dalam ajaran Hindu karena ia memiliki Tri Pramana (bayu, sabda dan idep) yakni mampu tumbuh/bergerak pindah tempat, berbicara dan berfikir). Sebuah kelebihan manusia dari mahluk lain dikatakan karena ia mempunyai pikiran yang tidak dimiliki mahluk lain. 


\section{Amalan Sampaingat Local Genius Hindu Kaharingan}

Komang Suarta

Memperhatikan beraneka pola hidup manusia dari zaman dulu sampai sekarang, ada sebuah pola hidup seimbang yang tumbuh dalam ajaran agama Hindu yang telah diperkenalkan kepada umat manusia, yang selalu diamalkan oleh para Yogi dalam kehidupannya. Pola hidup tersebut dikenal dengan istilah Yoga. Secara umum yoga telah dikenal oleh umat manusia, bukan hanya dari kalangan umat Hindu itu sendiri, namun juga diminati dari non-Hindu. Manusia tidak perlu menghabiskan waktunya untuk membahas tentang agama ataupun kebudayaan serta sebuah konsep. Dengan mengenal dirinya sendiri, manusia tidak akan bertengkar atas nama agama, budaya ataupun konsep yang dibuatnya. Manusia yang telah mengenal dirinya sendiri, maka ia akan memperoleh suatu kedamaian. Itulah yang diajarkan oleh Maha Rsi Patanjali yang merupakan pendiri filsafat yoga. Yoga adalah salah satu aktivitas yang menggambarkan penyeimbangan antara tubuh, pikiran dan jiwa. Yoga juga sebuah teknik yang mampu mencerdaskan diri manusia.

Di samping ajaran yoga, dengan memperhatikan local wisdom (kebijaksanaan lokal) dari suatu tempat melalui berbagai pengamatan atau penelitian yang mendalam, maka keuniversalan dari pengetahuan itu pasti akan kita temukan dalam bentuk local genius (kecerdasan setempat). Melirik sebuah ajaran leluhur Dayak yakni dalam ajaran Hindu Kaharingan Kalimantan Tengah, maka banyak hal yang akan kita temukan sebagai suatu hal yang diwariskan kepada generasinya sebagaimana dapat kita jumpai kearifan local dalam bentuk kecerdasan setempat "local genious". Manusia akan menjadi cerdas apabila pikirannya terasah. Untuk menjadikan pikiran manusia itu cerdas, leluhur Dayak Hindu Kaharingan Kalimantan Tengah melakukan penelitian terhadap isi alam semesta ini dan menemukan sesuatu yang mampu menjadikan daya ingat manusia begitu kuat.

Dengan memperhatikan aspek muatan lokal dan berwawaskan potensi keunggulan Hindu etnis Dayak Kalimantan Tengah, maka akan kita jumpai kearifal lokal seperti "hidup menyatu dengan alam". Kearifan lokal sangat diperlukan untuk menyiapkan sebuah generasi yang tidak hanya bisa menjadi penonton dalam sejarah peradaban, akan tetapi bisa menjadi pelaku sejarah dari peradaban itu sendiri. Dalam melestarikan kebijakan setempat "local wisdom" atau pengetahuan setempat "local knowledge"atau kecerdasan setempat "local genious", ajaran Hindu Kaharingan merupakan sumber untuk mempelajarinya. Agama Hindu Kaharingan merupakan agama asli Suku Dayak yang merupakan penduduk asli Kalimantan khususnya Kalimantan Tengah. Kearifan lokal adalah pandangan hidup dan ilmu pengetahuan serta berbagai strategi kehidupan yang berwujud aktivitas yang dilakukan oleh masyarakat lokal dalam menjawab berbagai masalah dalam pemenuhan kebutuhan mereka.

Satya Widya : Jurnal Studi Agama Vol. 3 No. 22020

DOI: https://doi.org/10.33363/swjsa.v3i2.592 
Berdasarkan uraian di atas, maka penulis tertarik untuk menghimpun kearifan lokal tersebut dalam sebuah tulisan dengan judul "Amalan Sampaingat Dalam Kehidupan Suku Dayak Hindu Kaharingan di Kaliamantan Tengah)”.

Berdasarkan uraian latar belakang di atas, maka dapatlah dirumuskan masalah Bagaimanakah bentuk Amalan Sampaingat Dalam Kehidupan Suku Dayak Hindu Kaharingan di Kaliamantan Tengah dan Apakah faktor pendukung keberhasilan Amalan Sampaingat Dalam Kehidupan Suku Dayak Hindu Kaharingan di Kaliamantan Tengah? Berdasarkan rumusan masalah di atas, maka tujuan penulisan ini adalah Untuk mengetahui bentuk Amalan Sampaingat Dalam Kehidupan Suku Dayak Hindu Kaharingan di Kaliamantan Tengah dan Untuk mengetahui faktor pendukung keberhasilan Amalan Sampaingat Dalam Kehidupan Suku Dayak Hindu Kaharingan di Kaliamantan Tengah.

Adapun manfaat dari penulisan ini adalah secara teoritis; sebagai pemicu bagi para peneliti untuk melakukan penelitian secara mendalam tentang hal ini dan sebagai petunjuk untuk mengamalkan ajaran ini sehingga terbentuk manusia-manusia yang cerdas bagi masyarakat Dayak khususnya pada umat Hindu Kaharingan

\section{Pembahasan}

\section{Bentuk Amalan Sampaingat Dalam Kehidupan Suku Dayak Hindu Kaharingan di Kaliamantan Tengah}

Sebelum membahas apa yang telah menjadi rumusan masalah dalam tulisan ini, maka akan diuraikan terlebih dahulu secara singkat tentang alam semesta dalam perspektif Hindu Kaharingan.

\section{Pengertian Sampaingat}

Manusia memiliki karakter yang beraneka ragam, baik dalam perilaku dan kecerdasannya. Ada yang penurut dan mengikuti arahan atau sesuatu yang diajarkan kepadanya. Ada juga yang tidak menanggapi apa yang disampaikan bahkan tidak menghiraukannya sehingga apa yang telah diajarkan kepadanya tidak bisa diingat dengan baik. Ada yang mudah mengerti dan mengingat segala sesuatu yang diajarkan, ada pula yang harus diajari secara berulang-ulang, bahkan ada pula yang telah berulang-ulang diajari namun kemampuan menangkap pelajaran tersebut tidak dapat diterima dengan baik. Setiap orang tentu menginginkan agar memiliki ingatan yang kuat. Banyak cara yang dilakukan untuk menguatkan ingatan. ada yang dilakukan dengan memenuhi asupan nutrisi tubuh. Ada pula yang dilakukan dengan disiplin berlatih yoga sehingga memperoleh keseimbangan tubuh, pikiran dan jiwa dan lain sebagainya.

Di Kalimantan Tengah, leluhur Suku Dayak dikenal memiliki teknik untuk membuat daya ingat seseorang bisa kuat. Misalnya para Kandong, 
Basir, Pisor dan para rohaniawan Hindu Kaharingan lainnya. Mereka dikenal dengan kemampuan daya ingatnya dalam merafal berbagai mantra, bahkan dalam berhari-hari pelaksanaan ritual mereka tetap mampu menghafalkan isi mantra-mantra tersebut yang jika ditulis dalam sebuah buku isinya puluhan bahkan ratusan halaman. Kemampuan mengingat tersebut tidak diperoleh begitu saja, namun melalui sebuah proses yang secara disiplin menerapkan metode yang diajarkan oleh leluhurnya. Ketika mulai berguru, mereka mengawalinya dengan kegiatan yaitu menerapkan sebuah metode yang disebut Amalan Sampaingat.

Sampaingat adalah kumpulan dari suatu hal yang dapat membuat seseorang memiliki kemampuan mengingat yang tinggi. Diperolehnya sistem amalan tersebut tidaklah mudah. Leluhur Dayak dikenal dengan penyatuannya terhadap alam. Melalui penyatuannya dengan alam, mereka bisa mengenal hal-hal yang bermanfaat untuk kehidupannya. Inilah merupakan bentuk dari sebuah upaya dalam pendidikan yang menjadikan alam sebagai tempat berlangsungnya proses pendidikan atau dengan kata lain, alam merupakan lingkungan dalam proses pendidikan. Mengenai hal ini, menurut Zuriah (2006: 101) menyatakan bahwa "Pendidikan sebagai proses sosialisasi pada hakikatnya adalah interaksi manusia dengan lingkungannya yang membentuknya melalui proses belajar dalam konteks lingkungan yang berubah-ubah".

Interaksi leluhur Dayak dengan alam yang dilakukan secara kontinu merupakan sebuah bentuk pendidikan. Dalam ajaran Hindu Kaharingan bahwa alam ini telah disiapkan dan dimanfaatkan untuk kehidupan manusia.

Hetuh AKU maatuh kakare gawi akan ketun sintung ndue; ketun sintung ndue mahaga hayak manguasa kakare taluh handiai ije jadi injadian awiKU, sama kilau AKU jadi manjadian tuntang mahaga ketun sintung ndue (Panaturan, pasal 4 ayat 10).

Artinya:

Sekarang aku mengatur segala tugas bagi engkau berdua; engkau berdua memelihara dan berkuasa atas segala yang telah AKU jadikan, sebagaimana AKU menjadikan dan memelihara engkau berdua (MBAHK Pusat, 2019: 19).

Kitab suci Panaturan mengajarkan bahwa manusia telah dianugrahi keistimewaan yaitu berkuasa atas segala yang telah diciptakan oleh Tuhan. Keistimewaan yang dimiliki manusia membuatnya mampu menundukan isi alam semesta ini. Kemampuan menundukan alam semesta ini karena manusia telah dianugrahi pikiran. Kitab suci Panaturan juga mengajarkan agar selain memanfaatkan/ berkuasa atas apa yang telah diciptakan Tuhan, manusia juga hendaknya senantiasa memelihara alam yang telah diciptakan oleh Tuhan sebagaimana Tuhan telah menciptakan dan memelihara manusia itu sendiri. Melalui ajaran tersebut, hendaknya manusia menjadi mahluk bijaksana 
sebagaimana yang diperintahkan Tuhan kepadanya, dan itu diperolehnya dari kemampuan berpikir yang telah dianugrahkan Tuhan kepada Manusia.

Menurut Cudamani (1993: 81) ditinjau dari segi arti kata, manusia berasal dari kata manushya yang berarti mahluk yang memiliki pikiran”. Dengan pikiran tersebut, manusia dianugrahi kemampuan untuk membedakan yang baik dan yang buruk. Dalam susastra Hindu juga memberikan keutamaan lahir sebagai manusia, yakni sebagai berikut:

Manusah sarwa bhutesu warttate wai subhaashube, acubhesu samawistam cubheswewa wakarayet (Sarasamuscaya 1.2).

Artinya:

Dari demikian banyaknya semua mahluk hidup, yang dilahirkan sebagai manusia itu saja yang dapat berbuat baik dan buruk, kemampuan melebur perbuatan buruk ke dalam perbuatan baik, demikianlah pahalanya menjadi manusia.

Melalui pikiran yang dimiliki, leluhur Dayak berbaur dengan alam dari waktu ke waktu. Dalam keyakinan leluhur Dayak bahwa Tuhan yang maha pengasih dan penyayang tersebut keberadaannya dapat dibuktikan melalui segala sesuatu yang telah disediakan Tuhan untuk memenuhi kebutuhan manusia dalam kehidupannya. Berbagai petunjuk diperoleh ketika menyendiri dan mengamati alam. Salah satunya adalah tentang cara untuk membuat manusia memiliki daya ingat sebagai kecerdasan intelektual yang disebut Sampaingat. Hal tersebut kemudian diajarkan melalui cerita dari satu generasi ke generasi selanjutnya.

Lebih lanjut menurut Zuriah (2006: 102) bahwa tekanan utama pada pendidikan adalah pada pembinaan dan pengembangan kepribadian manusia mencakup aspek intelektual, moral sosial dalam satu kesatuan utuh, serasi, selaras dan seimbang. Pembinaan dan pengembangan tersebut melalui proses belajar agar diperoleh perubahan perilaku menyangkut pengetahuan, sikap dan keterampilan.

Dengan demikian, maka tekanan dari amalan Sampaingat tersebut adalah mendukung capaian dari tujuan pendidikan yakni pengembangan kepribadian dalam aspek pembentukan intelektual yang cerdas. Kecerdasan intelektual pada akhirnya akan menghantarkan manusia menjadi mahluk yang mulia, manusia yang seutuhnya, sehingga konsep manusia Dayak yang sempurna akan terwujud. Konsep manusia seperti itu dapat digambarkan sebagai berikut:

Bitim batakuluk bangun tarajun ambu, baramate bulau pungkal raja, bakining bulau batutuk sangkalemu, bajela bulau batangep rabia, baiweh nyalung kaharingan belum, basilu ruhng bataji tihil, bakatetes hinting bunu panjang, baratap hinting kamarau ambu, bakatutuh bulau lelak bendang, batingkai rabia bahinis kereng, baragana anak 
antang baputi, belum bahalap limu-limut bulue, hapanduyan nyalung kaharingan belum, hapupuk guhung paninting tahaseng, tantausik jatha-hatalla.

Artinya:

Jadilah manusia yang mempunyai akal pikiran seperti taraju yang adil dan timbangan yang benar, mempunyai pandangan yang luas. Ia pandai melihat dan memilih mana yang benar serta mana yang salah.mana yang adil dan mana yang tidak adil. Cahaya matanya memancarkan cahaya keadilan dan perlindungan, rasa aman dan rasa bhakti. Apa yang diucapkan benar dan berguna, lidahnya hanya mengucapkan hikmat dan kebenaran, perdamaian. Air liurnya mengalirkan air kehidupan yang tidak kering-keringnya. Tangan dan segala geraknya penuh budi dan perdamaian. Pandai memutuskan perkara dengan adil dan jujur serta berbuah kemakmuran yang merata, ia selalu beriman dan menjadi contoh dan teladan bagi umat sesama, disenangi dan disegani dimanapun ia berada. Ia selalu membersihkan dan mensucikan diri dan jiwanya. Dengan demikian ia akan selalu diberkati dan diberi rahmat oleh Zat Yang Maha Suci atau Ranying Hatalla (Toendan, 2005: 25-26).

\section{Bentuk Amalan Sampaingat}

Mahluk hidup tak terkecuali manusia memiliki rasa keingintahuannya dalam rangka ingin mempertahankan kelestarian hidupnya. Ketika menjumpai sebuah tampilan bentuk dari sesuatu yang unik, pada saat itulah mulai ada ketertarikan untuk mengamatinya. Dalam Kamus Besar Bahasa Indonesia, kata bentuk dapat berarti:
a. Lengkung, lentur,
b. Gambaran,
c. Rupa, wujud,
d. Sistem, susunan,
e. Wujud yang ditampilkan (tampak), dan
f. Acuan atau susunan kalimat (Tim 1995: 103-104).

Setelah ada ketertarikan terhadap sesuatu yang diperhatikan tersebut, maka dilakukanlah sebuah perenungan terhadap hal yang diperhatikan tersebut. Berbeda halnya dengan mahluk hidup lainnya, manusia memiliki kelebihan berupa kemampuan berpikir untuk mengembangkan rasa ingin tahunya, meskipun diawali dengan pemikiran sederhana dengan cara prasangka, intuisi dan metode coba-coba (Trial and error) untuk menjawabnya. Perilaku hewan yang ditentukan secara genetik (tropisme, taksis/kinetis, refleks, naluri/insting), sementara perilaku perolehan (inquired) didapat sebagai hasil belajar seperti: habituasi, pengkondisian, perekaman, meniru, coba-coba dan menalar). 


\section{Amalan Sampaingat Local Genius Hindu Kaharingan}

Komang Suarta

Dalam menemukan pengetahuan/kebenaran, pada awalnya manusia menggunakan pendekatan non-ilmiah (Pseudoscience) yaitu lewat wahyu yang diterima oleh orang-orang suci (Rsi/Rasul) Tuhan. Menurut Randall, Buchler dan Titus (Arlina, 1985) menyatakan bahwa ada beberapa upaya yang dilakukan oleh manusia untuk mendapatkan pengetahuan/kebenaran yang sifatnya non-ilmiah, antara lain:

1. Akal Sehat (Comonsence)

2. Apriori (Praduga)

3. Intuisi

4. Prasangka

5. Coba-coba (Trial and Error)

6. Pendapat tokoh yang berpengaruh

7. Wahyu

Pemanfaatan alam semesta untuk meringankan beban atau membantu manusia dalam menjalani hidupnya adalah salah satu ciri dari masyarakat Dayak Kalimantan Tengah. Amalan Sampaingat pada dasarnya dilakukan dengan proses menginang. Sarana menginang terdiri atas buah pinang, sirih, kapur sirih, gambir dan tembakau. Untuk amalan sampaingat, maka kelengkapan menginang tersebut ditambah dengan daun Panyalembang, Parinting, Kapapulut, Kayu Leket.

\section{1) Pinang}

Pinang merupakan salah satu tumbuhan berkeping satu, dengan nama Latin Areca Catechu. Tumbuhan Pinang tentu tidak asing lagi dalam kehidupan masyarakat di Indonesia. Demikian pula halnya dalam kehidupan masyarakat Dayak di Kalimantan Tengah. Selain menjadi salah satu komoditi eksport, buah Pinang di Kalimantan Tengah oleh masyarakat Dayak senantiasa menjadi salah satu kelengkapan dalam menginang. Ketika menginang, pinang yang digunakan tergantung selera masing-masing. Ada yang menggunakan buah Pinang tua, ada pula yang menggunakan buah pinang yang masih muda. Berkenaan dengan amalan Sampaingat ini, Pinang yang digunakan adalah Gehat/ Pinang Mangur yaitu pinang muda yang masih ada air yang terkurung di dalamnya. Pinang tersebut tidak boleh diambil dengan cara menjatuhkannya dari pohonnya, namun dilakukan dengan cara memanjat pohon pinang tersebut dan membawanya turun dengan menggigit tundun dari buah pinang muda tersebut. Pinang muda tersebut dibuang kulit keras bagian luarnya saja, dengan tetap menyisakan serabut pinang muda tersebut. 
Gambar 1

Pinang Muda

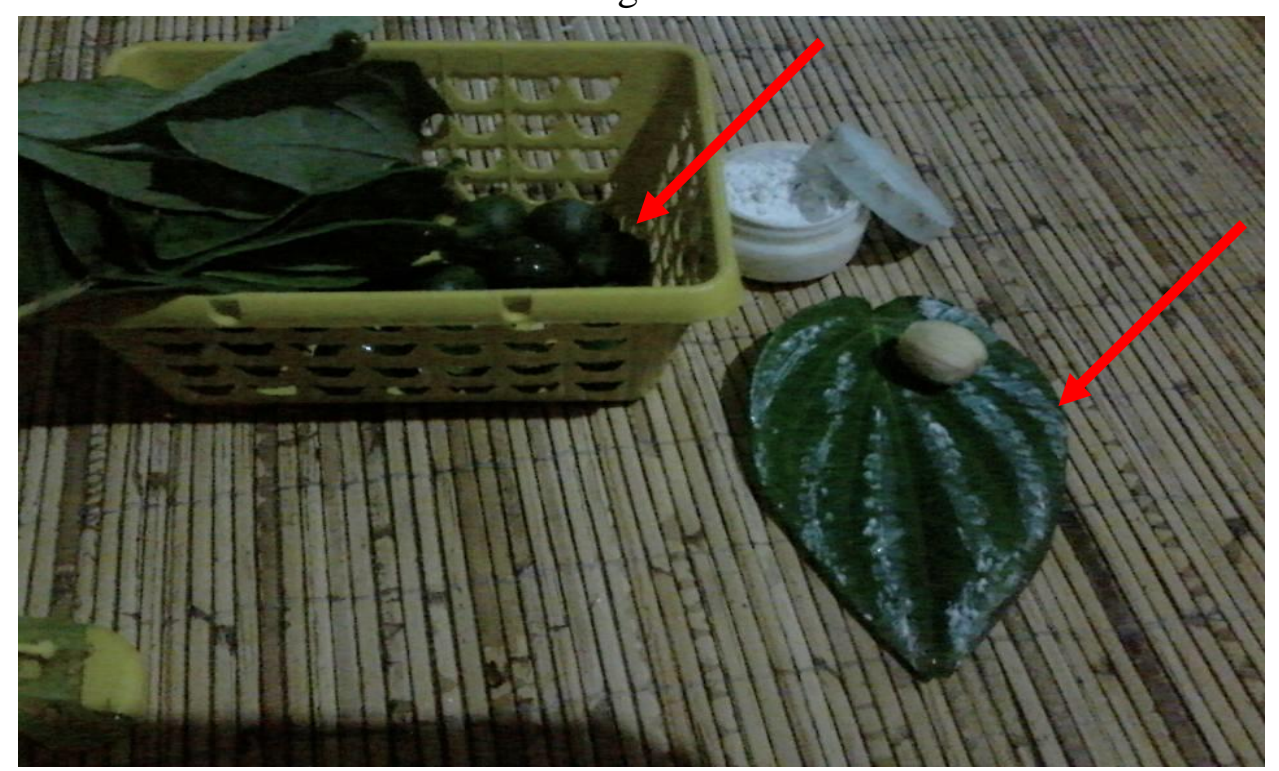

Sumber: Dokumentasi Komang Suarta

Berdasarkan Purana/ cerita yang terdapat dalam kitab suci Panaturan, bahwa Pinang berasal dari Saluh Palin Bambang Penyang dari Mangku Amat Sangen dan Nyai Jaya Sangiang, yakni dari biji matanya. Dari roh kemahakuasaan Mangku Amat Sangen dan Nyai Jaya Sangiang yang menyatu pada pinang, diharapkan agar segala bentuk pengetahuan yang berasal dari bentuk/ rupa dapat ditangkap dengan baik oleh indra penglihatan yaitu mata.

\section{2) Sirih}

Sebagaimana halnya dengan Pinang, Sirih juga merupakan salah satu tumbuhan menjalar yang dikenal dalam kehidupan masyarakat Indonesia. Tumbuhan ini memiliki nama Latin Piper Betle. Khususnya di Kalimantan Tengah, ada berbagai macam Sirih yang dikenal oleh masyarakat Dayak, antara lain Sirih Bahandang, Sirih Haramaung, Sirih Padas, Sirih Jarenang dan sebagainya. Untuk amalan sampaingat, maka sirih yang digunakan adalah Sirih Jarenang yakni sirih yang memiliki urat kemerahan. Sirih jarenang yang digunakan juga yang Tanturung Tulang yakni urat-urat pada bagian kedua belah sisinya saling bertemu antara satu dengan yang lainnya. 


\section{Gambar 2}

Sirih Jarenang Tanturung Tulang

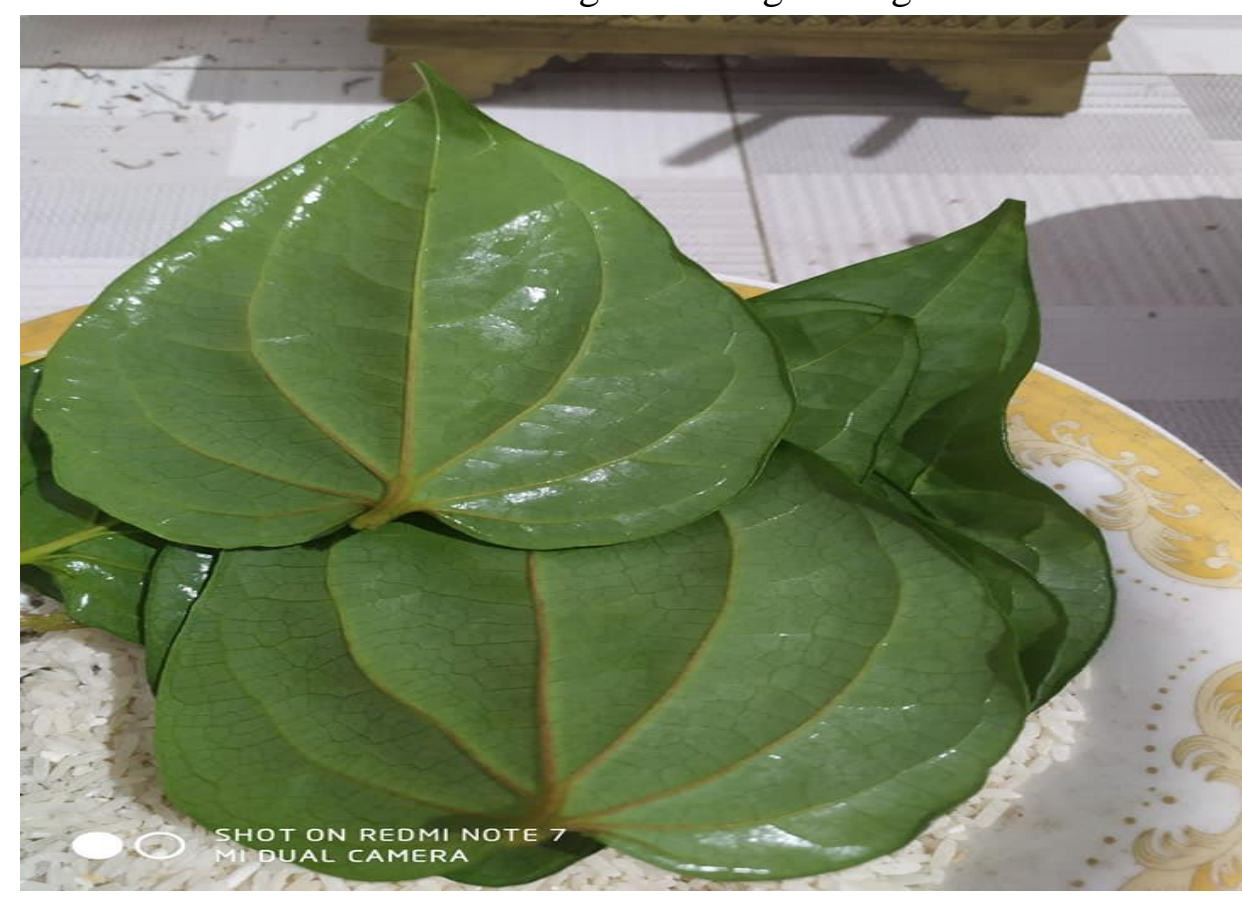

Sumber: Dokumentasi Komang Suarta

Berdasarkan Purana/ cerita yang terdapat dalam kitab suci Panaturan, bahwa Sirih berasal dari saluh palin bambang penyang dari Mangku Amat Sangen dan Nyai Jaya Sangiang, yakni dari daun telinganya. Dari roh kemahakuasaan Mangku Amat Sangen dan Nyai Jaya Sangiang yang menyatu pada sirih, diharapkan agar segala bentuk pengetahuan yang berasal dari gelombang suara dapat ditangkap dengan baik oleh indra pendengaran yaitu telinga.

\section{3) Kapur Sirih}

Kapur sirih adalah kapur yang terbuat dari olahan Cangkang dari berbagai jenis kerang sungai atau laut, Cangkang berbagai jenis kura-kura, namun secara umum masyarakat Dayak Kalimantan Tengah menggunakan Cangkang dari Kerang Sungai sebagai bahan dasar pembuatan Kapur Sirih. Berdasarkan Cerita dalam kitab suci Panaturan, bahwa Kapur Sirih berasal dari Otak Saluh Palin Bambang Penyang dari Mangku Amat Sangen dan Nyai Jaya Sangiang. 


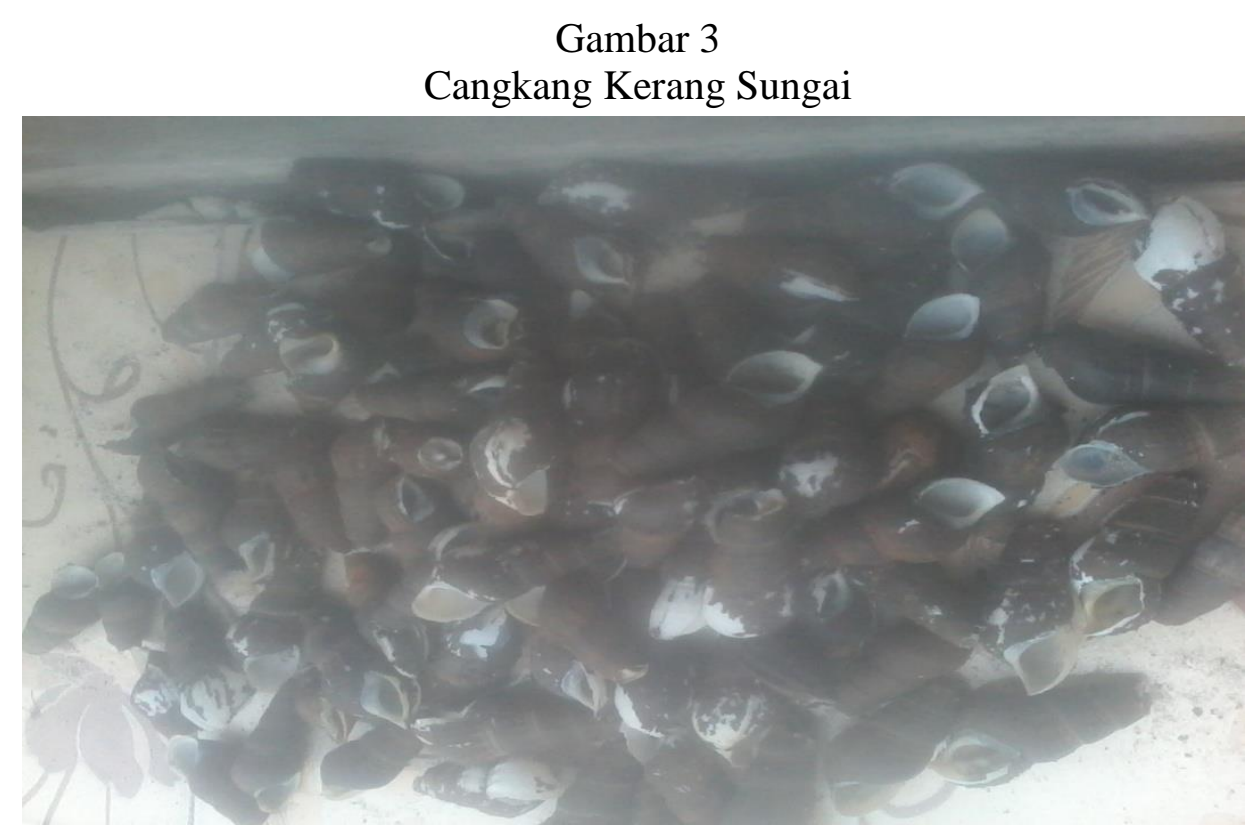

Sumber: Dokumentasi Komang Suarta

Masyarakat dayak Kalimantan Tengah memiliki keterampilan dalam mengolah Cangkang Kerang tersebut menjadi Kapur Sirih tersebut. Cangkang dari kerang atau kura-kura tersebut dibakar dengan menggunakan bambu yang sudah kering. Menyusun tumpukan bambu dalam beberapa susun, lalu meletakan seng di atas tumpukan itu. Selanjutnya meletakan tempurung kerang-kerang tersebut di atas seng dan menutupnya dengan potongan bambu kering berlapis-lapis di atas kerangkerang tersebut. Proses pembakaran kurang lebih selama 30 sd 60 menit dengan menjaga nyala api dari potongan bambu yang sudah disiapkan. Setelah api padam dan sudah tidak ada bara api yang tersisa menyala, maka abu dari sisa pembakaran tadi dikipas-kipas agar abu yang menutupi kerang tersebut terbang dan terpisah dari kerang yang telah terbakar. Akan terlihat Cangkang Kerang yang sudah terbakar tersebut berwarna keputihan. Sambil menunggu tempurung tersebut dingin, maka disiapkan tempat yang berisi air secukupnya, menyesuaikan dengan banyaknya tempurung kerang yang dibakar tersebut. Setelah dingin, maka kerang tersebut diambil dengan Katip yaitu alat penjepit yang terbuat dari bambu dan menaruhnya pada tempat yang sudah disiapkan tadi. Ketika tempurung kerang yang sudah dibakar tadi menyentuh air dingin yang disiapkan pada tempat tersebut, maka air dingin tadi akan segera mendidih panas, sehingga jika orang yang tidak mengetahuinya bisa berbahaya karena panasnya air tersebut sebagaimana panasnya air mendidih yang direbus dan mencapai suhu 90 derajat celcius. Kapur tersebut akan segera hancur luluh dan menjadi adonan kapur sirih yang siap digunakan untuk kelengkapan menginang. 


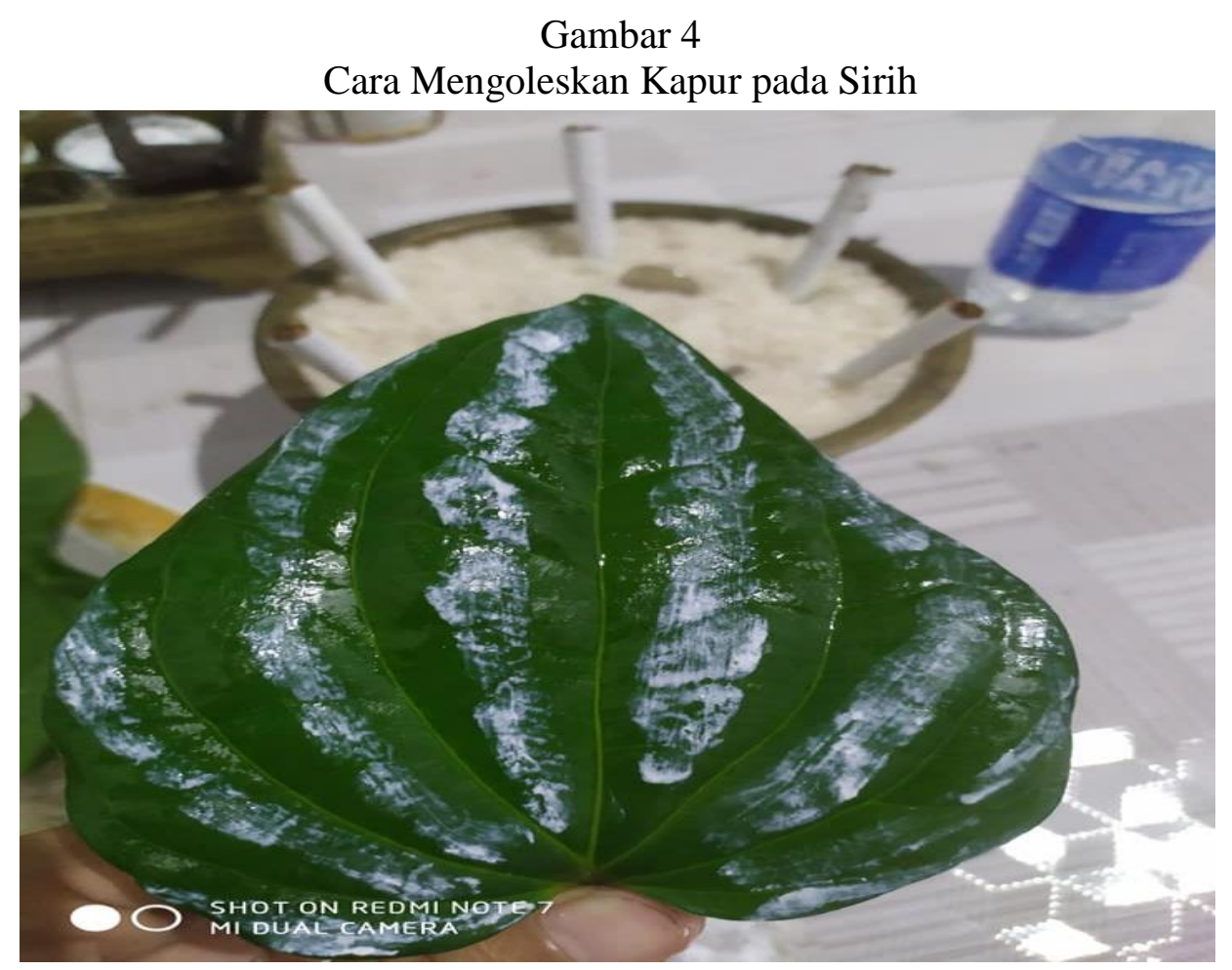

Sumber: Dokumentasi Komang Suarta

\section{4) Gambir}

Gambir adalah salah satu jenis tumbuhan yang digunakan sebagai kelengkapan saat menginang. Bagian yang digunakan bisa dari bagian daunnya, bisa pula dari olahan getahnya.

\section{5) Parinting}

Parinting adalah nama dari salah satu tumbuhan yang memiliki bentuk daun seperti mata tombak yang pada kedua belah sisinya terdapat benjolan-benjolan kecil yang tersusun dengan jarak yang sama antara sisi kiri dan kanannya. Karena memiliki benjolan yang tersusun rapi tersebut, maka Dawen Parinting disebut juga Dawen Paretei yang berarti daun yang memiliki sesuatu yang tersusun rapi secara berurutan. Daun ini diyakini sebagai sebuah tumbuhan yang membuat seseorang mampu memiliki keteraturan dalam menyampaikan informasi yang berstruktur dan mudah dipahami oleh penerima informasi. Dengan harapan agar manusia memiliki kemampuan berbicara yang baik dan teratur, maka Parinting ini disebut sebagai tumbuhan yang berfungsi sebagai paretei kutak penyusun ucapan/ perkataan.

\section{6) Panyalembang}

Panyalembang adalah sejenis tumbuhan menjalar, yang memiliki ciri daun berlubang-lubang. Untuk amalan sampaingat, bagian tumbuhan ini yang diambil adalah daunnya. Di antara daun-daun tumbuhan panyalembang 
tersebut, terdapat lubang yang berjumlah genap, ada pula yang berjumlah ganjil. Untuk amalan panyalembang maka dipilh lubang yang ganjil, seperti 3, 5, 7, 9 dan sebagainya. Sebagai kelengkapan manyipa, cukup diambil salah satu lubang pada lubang-lubang yang terdapat pada daun Salembang tersebut. Amalan sampaingat dengan menggunakan daun Salembang ini dilakukan sebanyak 3 sampai dengan 7 kali yang dilakukan pada hari Jumat pagi. Untuk anak-anak yang ubun-ubunnya masih terdapat cekokannya (balita) dilakukan dengan menjadikan daun Salembang tersebut sebagai sarana untuk keramas pada bayi tersebut saat dimandikan.

Gambar 5

Daun Salembang

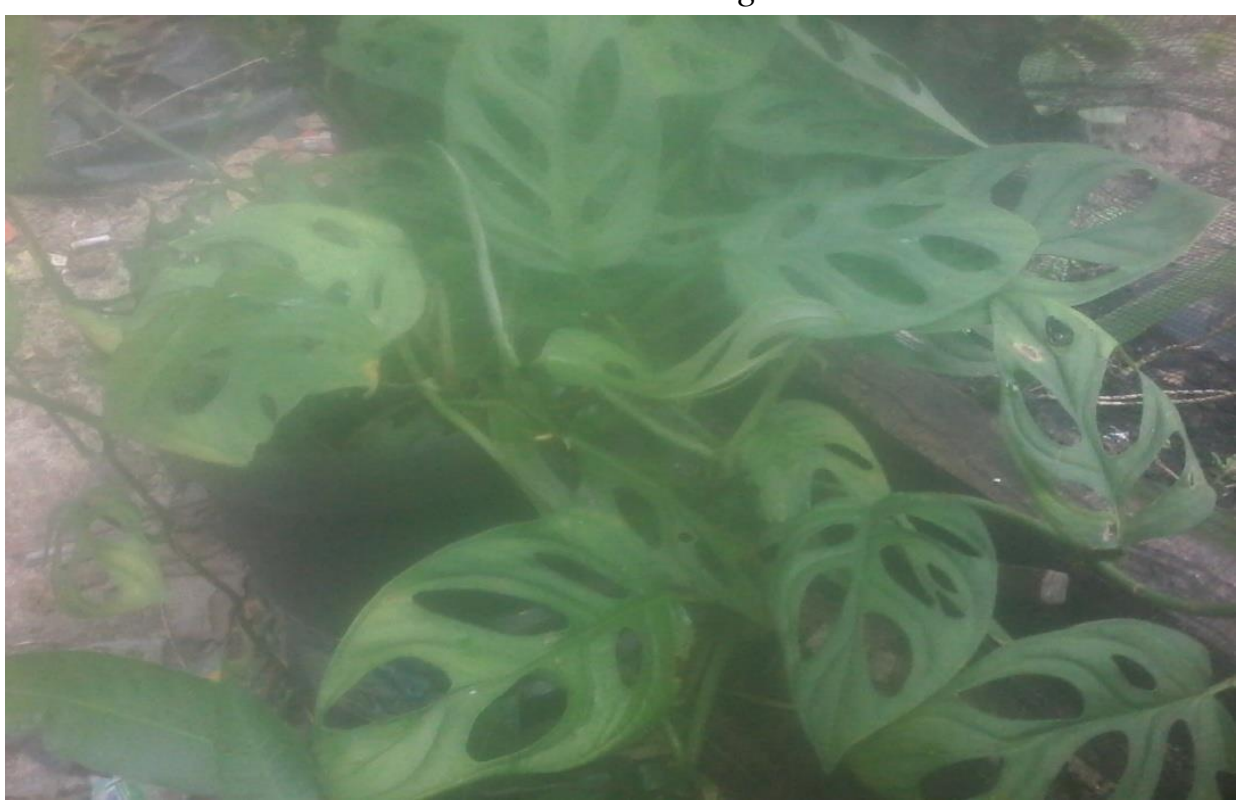

Sumber: Dokumentasi Komang Suarta

\section{7) Paleket}

Paleket adalah sebuah benda berupa Tumbuhan yang memiliki fungsi untuk membuat sesuatu yang diharapkan bisa melekat atau lengket. Ada beberapa benda yang tergolong sebagai ramuan untuk membuat daya ingatan yang dimiliki oleh manusia menjadi kuat/ lengket dalam pikiran. Benda tersebut antara lain Bua Kapapulut dengan Kayu Leket.

\section{a) Kapapulut}

Kapapulut adalah sejenis rumput yang memiliki ciri buah bulat kecil yang dikelilingi serabut agak tajam dan apabila tersentuh kain ia akan lengket dan menyangkut pada kain tersebut. Bagian-bagian dari tumbuhan ini yang diambil yakni akar, daun dan buahnya. Bagian akar dan buahnya digunakan untuk Sipa atau menginang, sementara daunnya digunakan untuk keramas. Ketika mengambil tumbuhan ini untuk digunakan, maka secara etika diwajibkan untuk menggantinya 
dengan garam dan paku (besi) atau bisa pula ditambah dengan abu, dengan maksud sebagai pengganti dan permohonan ijin untuk mengambil dan menggunakannya berdasarkan hakikat hati sesuai maksud benda tersebut di ambil. Untaian doa sederhana tersebut berbunyi "kilau buam ije malengket tuh, malengket kia narai auh ije inantuajar, ije bahalap akan galang pambelumku" yang berarti sebagaimana buahmu yang lengket ini, lengket pula apa saja yang dipelajari, menjadi sesuatu yang baik sebagai bekal kehidupanku.

Gambar 6

Tumbuhan Kapapulut

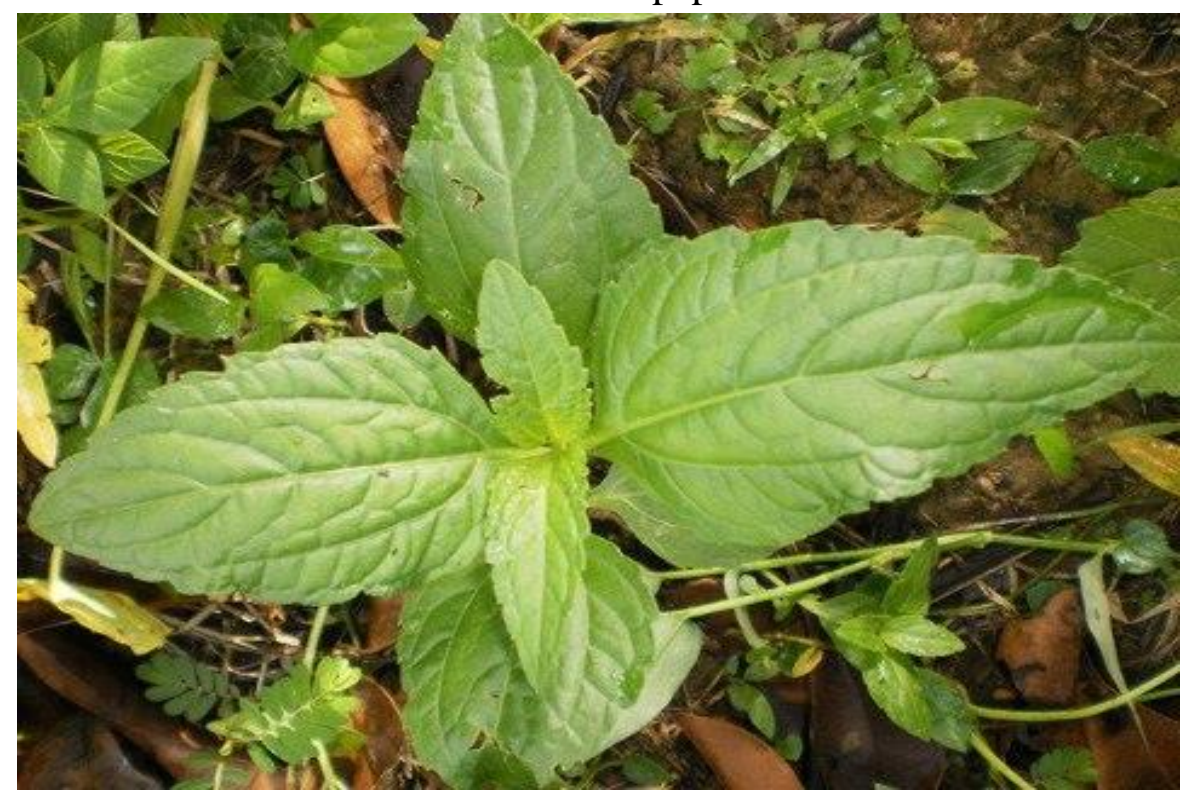

Sumber: Dokumentasi Komang Suarta

\section{b) Kayu Leket}

Kayu leket adalah kayu yang menempel dan menyatu atau menembus antara satu dengan yang lainnya. Leluhur Dayak senantiasa berbaur dengan alam, sehingga apa yang diamatinya secara berkelanjutan akan memberikan petunjuk tentang manfaatnya untuk kehidupannya. Sebagaimana Kayu Leket yang keadaan tidak lazim tersebut, maka dengan hakikat pikiran sebagaimana halnya keadaan kayu tersebut, maka kayu tersebut diambil untuk digunakan sebagai Paleket.

Bahan/ sarana untuk amalan Sampaingat yang digunakan sebagai kelengkapan dalam menginang. Sebelum menginang dengan kelengkapan ini, maka seseorang terlebih dahulu harus sudah terbiasa menginang. Rasa pedas, kalat, pahit akan dirasakan mengganggu bagi para penginang pemula. Apalagi jika awal belajar menginang diperoleh jenis Pinang Busau yakni buah pinang yang bisa menyebabkan mabuk dan mual. Seseorang yang telah terbiasa menginang akan merasakan sebuah rasa yang nikmat, bahkan

Satya Widya : Jurnal Studi Agama Vol. 3 No. 22020 
cenderung seperti kecanduan. Walaupun bisa menyebabkan kecanduan, akan tetapi kebiasaan menginang tidak memiliki dampak negative, bahkan cenderung memberikan dampak yang baik untuk kesehatan.

Selain dengan proses menginang, amalan sampaingat juga bisa dilakukan pada saat proses memandikan anak, yakni untuk anak-anak yang masih terdapat cekokan pada ubun-ubunnya. Adapun sarana yang digunakan antara lain batang Kajajak dan daun Panyalembang dan daun Kapapulut. Kajajak diambil sebanyak 7 ruas sepanjang kepalan telapak tangan lalu diikat menjadi satu. sebelum anak dimandikan, maka kajajak tersebut direndam bersama dengan daun panyalemang dan daun kapapulut. Ketika memandikan bayi, 7 kayu kajajak tersebut ditiupkan pada masing-masing ubun-ubun, kedua mata, kedua lubang telinga, kedua lubang hidung dan pada mulutnya. Adapun hakikat doa disampaikan sebagai berikut:

Himunku riwut je basuang danum mahapan batang kayu Kajajak tuh mahalau matae tuh, mangat narai bewei tampayah matae tau leket akan pangingat ah, saluh jadi pangatawan akan galang pambelum ah. Himunku tinai riwut je basuang danum mahpan batang kayu Kajajak tuh mahalau pinding ah, kilau te kea mangat narai bewei je nyeneh ah tau leket akan pangingat ah, saluh jadi pangatawan akan galang pambelum ah. Himunku riwut je basuang danum mahpan batang kayu Kajajak tuh mahalau urung ah mangat ewau narai bewei ije kamea tau leket huang pangingat ah, tuntang basaluh jadi pangatawan akan pambelum ah. Himunku tinai riwut je basuang danum mahapan batang kayu Kajajak tuh mahalau tutuk jela ah, kilau te kea mangat narai bewei je ngutak pander ah tau saluh jadi pangatawan akan tanggeran lewu mandereh danum tangkilik rundung hapamantai tambun. Palus tende himunku riwut je basuang danum mahapan batang kayu Kajajak tuh mahalau batu junjun karepurun jakat liang lambaran lawin balau panjang, hajamban hambaruae mimbit kapintar hayak kaharati, panyalemang untek panarang atei, parentas rawei paretei kutak, paharus jalan parajang tutur, mangat narai bewei bara tampayah, panyeneh, pangkeme, tuntang pander sarita tau manjadi sampaingat huang pambelum ah, sahie.

Satya Widya : Jurnal Studi Agama Vol. 3 No. 22020

DOI: https://doi.org/10.33363/swjsa.v3i2.592 
Gambar 7

Batang Kajajak

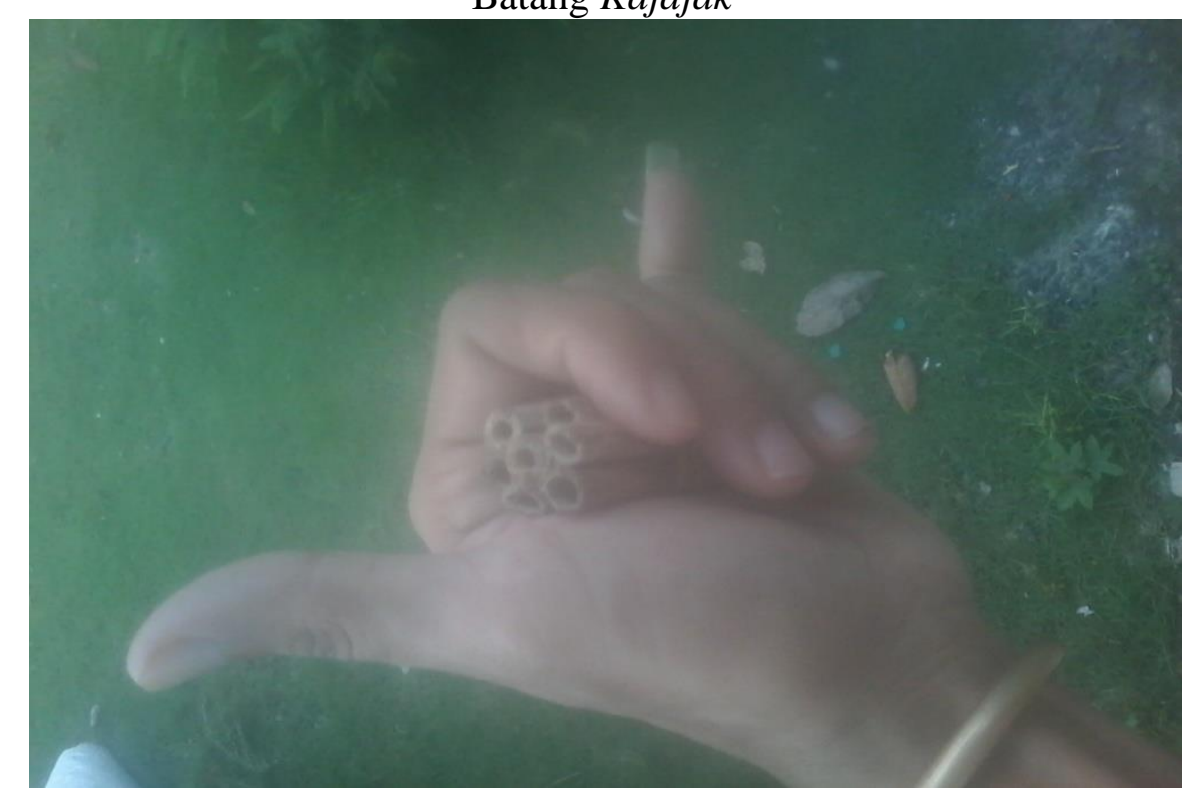

Sumber: Dokumentasi Komang Suarta

\section{Faktor Pendukung Keberhasilan Amalan Sampaingat Dalam Kehidupan Suku Dayak Hindu Kaharingan Di Kaliamantan Tengah}

Berbagai sarana yang digunakan sebagai amalan Sampaingat ini telah diyakini secara turun-temurun oleh masyarakat Dayak untuk membuat seseorang memiliki ingatan yang baik, terlebih pada kegiatan Batamat dalam Pelatihan Balian. Terbentuknya daya ingat yang baik merupakan harapan yang diinginkan oleh orang-orang yang melakukan amalan sampaingat ini. Agar tingkat keberhasilannya baik, maka ada beberapa faktor pendukung yang hendaknya dipatuhi oleh mereka. Amalan Sampaingat ini akan menunjukan fungsinya ketika faktor penentu berupa Pali atau larangan dan sebagainya ketika mengamalkannya dipatuhi dengan baik.

Ada beberapa larangan atau Pali ketika melakukan amalan sampaingat. Pali adalah bentuk amalan sebagai sebuah bentuk kedisiplinan yang harus dilakukan selama proses berlangsung. Adapun pali tersebut antara lain:

1. Tidak boleh Nyipal menginang dimpah jela. Ketika menginang posisi bahan-bahan kinangan hanya pada salah satu bagian rahang, tidak boleh berpindah-pindah kesebelah. Jika dilakukan pada rahang kanan, maka sampai selesai proses menginang tesebut bahan-bahan kinangan tersebut dikunyah pada rahang kanan, demikian pula sebaliknya. Disarankan agar menginang dilakukan pada bagian rahang kanan, dengan hakikat bahwa segala sesuatu yang dimasukan akan lebih baik jika meleati bagian kanan. Ketetapan untuk berada pada suatu sisi menunjukan bahwa seseorang yang 
memiliki ilmu pengetahuan diharapkan akan memiliki kedisiplinan dan kemampuan untuk kuat dalam ketetapan pendirian atau tidak dalam keterobang-ambingan. Pengetahuanlah yang akan menjadi pengarah sehingga ia memiliki keyakinan yang matang.

2. Tidak boleh menggunakan tempat untuk makan ataupun minum dari halhal yang berhubungan dengan petutup dari segala sesuatu, seperti tutup panci, tutup termos dan sebagainya. Hal ini bermakna bahwa pikiran yang tertutup akan berada dalam kegelapan sehingga tidak mampu mendapatkan pengetahuan sebagai bentuk pencerahan diri. Kegelapan pikiran akan membuat manusia tidak mampu meningkatkan kualitas pikirannya menjadi budhi/ kecerdasan intelektual.

3. Tidak boleh mengikutsertakan gelembung angin yang terdapat pada ikan, terutama jenis ikan yang besar untuk dimasak. Hal ini bermakna, agar jangan sampai tampilan luarnya saja yang menggambarkan seseorang punya ilmu pengetahuan, namun ketika digali lebih dalam sesungguhnya ada dalam kekosongan atau ketidaktahuan. Seseorang yang matang dengan ilmu pengetahuan harus sampai pada pengetahuan terdalam dari segala sesuatu.

4. Tidak boleh kencing dalam posisi berendam di dalam air.

5. Tidak boleh hasual-hajawab (bertengkar dengan saling jawab), Kalahikajamah (saling beradu fisik) sebagai bentuk pengendalian emosional harapan bahwa pengetahuan yang diperoleh untuk kebijaksanaan.

Pali tersebut merupakan faktor utama yang menjadi pendukung keberhasilan dalam amalan Sampaingat tersebut. Selain Pali atau larangan tersebut, seseorang yang sedang melaksanakan amalan Sampaingat harus memiliki keyakinan yang bulat, pikiran terpusat ketika mendengarkan, melihat, merasakan dan hal-hal yang berkenaan dengan penangkapan pengetahuan melalui indera yang dimiliki. Bahkan ada sebuah tradisi yang menyatakan bahwa "cukup tiga kali saja saya menyampaikan ini, jika tak mampu ditangkap maka pengetahuan tersebut belum layak engkau dapatkan. Untuk itu, jangan memikirkan hal lain ketika menyimak pelajaran, fokuskanlah pikiran itu terhadap apa yang ku sampaikan". Pernyataan ini kerap kali disampaikan oleh soerang guru pada muridnya dalam kehidupan perguruan yang dikenal dengan Sistem Pendidikan Mangaji, yakni sistem pendidikan tradisional Suku Dayak Kalimantan Tengah.

\section{Simpulan}

Amalan Sampaingat merupakan sebuah warisan dari leluhur Dayak Kalimantan Tengah yang merupakan sebuah metode untuk menciptakan kecerdasan pada orang yang mengamalkannya. Amalan ini terdiri atas dua cara, yakni melalui menginang dan dengan cara permandian (keramas). Amalan

Satya Widya : Jurnal Studi Agama Vol. 3 No. 22020 
sampaingat dengan menginang menggunakan beberapa sarana, seperti; Pinang, Sirih, Kapur Sirih, Gambir, Tembakau, Daun Panyalembang, Buah Kapapulut, Daun Parinting/ Paretei, dan Kayu Paleket. Sementara itu, Amalan Sampaingat yang digunakan melalui cara permandian yakni menggunakan sarana berupa; Batang Kajajak, daun Panyalembang, daun Kapapulut dan daun Untek Undang. Amalan ini mengajarkan agar masyarakat Dayak khususnya di Kalimantan Tengah selalu melakukan pembauran dan menjaga alam semesta. Ada beberapa Pali dalam menjalankan amalan Sampaingat. Pali tersebut mengajarkan agar kita memiliki ketetapan dalam pendirian, senantiasa membuka diri dengan tidak menutup pikiran untuk berbagai pengetahuan yang baik, tidak menjadi orang yang kosong/ dangkal pengetahuannya. Hal tersebut merupakan sebuah pendukung bagi seseorang agar bisa memiliki kecerdasan emosional dan kecerdasan spiritual sebagai pelengkap kecerdasan intelektualnya yang diperoleh melalui amalan Sampaingat tersebut.

\section{Daftar Pustaka}

1. Cudamani. (1993). Pengantar Agama Hindu. Jakarta: Hanuman Sakti

2. MB-AHK Pusat. (2019). Panaturan. Palangka Raya: MB-AHK Pusat

3. Kajeng, I Nyoman Dkk. (1997). Sarasamuccaya. Surabaya: Paramita

4. Toendan, Nusa J. (2005). Ikut Petuah Pantang Menyerah, Membangun Kalimantan Tengah. Palangka Raya: Yayasan Indonesia.

5. Zuriah,Nurul. ( 2006 ). Metodologi Penelitian Sosial dan Pendidikan Teori Aplikasi. Jakarta: Bumi Aksara. 